\title{
RESPONSE OF SOME SUGAR BEET VARIETIES TO FOLIAR SPRAY WITH COMPOST TEA UNDER NEWLY RECLAIMED SOILS.
}

\author{
Aly, M.S.M.; S.R.E. El-Sheikh and M. M. Abd El-Rahman \\ Sugar Crops Research Institute, Agricultural Research Center Giza, Egypt. \\ ABSTRACT
}

Two field experiments were carried out in a sandy soil at ElQureen, Sharkia Governorate Egypt during 2009/2010 and 2010/2011 seasons to study the response of some multigerm sugar beet varieties i.e., Top, Sultan and Kawemira to foliar spray at 60 and 75 days from sowing with three levels of compost tea $(0.0,1.5$ and 2 $\mathrm{L} / \mathrm{fed} / 300 \mathrm{~L}$ water). The experimental treatments were allocated in a split plot manner with four replications.

The obtained results showed that foliar spraying with compost tea at the level of $2.0 \mathrm{~L} / \mathrm{fed}$ significantly increased root length, diameter, fresh weight/plant, sucrose $\%$, purity\%, root and sugar yields/fed in both seasons. While, it decreased root mineral contents $(\mathrm{N}, \mathrm{Na}$ and $\mathrm{K} \%$ ) as compared with zero treatment (control) or $1.5 \mathrm{~L} / \mathrm{fed} \mathrm{level} \mathrm{of}$ compost tea.

Sugar beet varieties significantly differed for root length, diameter, fresh weight/plant, sucrose $\%$, purity $\%$ and root and sugar yields/fed, root mineral contents. Kawemira variety surpassed the other two varieties Sultan and Top in most studied traits in both seasons.

The interaction between foliar spraying with compost tea the at level of $2.0 \mathrm{~L} / \mathrm{fed}$ and Kawemira variety recorded the highest values for sucrose \%, root and sugar yields/fed in both seasons. Generally, it could be recommended that sown Kawemira, Sultan and Top varieties, respectively, sprayed with $2.0 \mathrm{~L} /$ fed compost tea to obtain the highest sucrose \%, root and sugar yields/fed and yield quality in a sandy soil at El-Qureen, Sharkia Governorate.

Key words: Sugar beet varieties, Foliar spray, Compost tea and Newly reclaimed soils.

\section{INTRODUCTION}

Sugar beet plays a prominent role in sugar production, about $37.27 \%$ of the local sugar production, which amounted to 1.61 million ton, is produced from sugar beet, which is considered the second sugar crop after sugar cane, $($ CCSC, 2010). Also, there is great interest among sustainable growers about the use of compost tea for increased crop health and fertility. Years of research and results in the field have demonstrated the power of this technology, which is growing in popularity, compost tea is a liquid solution or suspension made by steeping compost in water. It is used as both a fertilizer and in attempts to prevent plant diseases. The tea may be rapidly deactivated when foliar applied due to sunlight, rain and UV radiation. However, on the soil surface the microbes in the tea will colonize plant litter, debris and improve decay rates. (httd://en.wikipedia.org/wiki/composttea), compost tea extracts prepared from composted manure, composted pine bark, an organic farm composted, or cattle yard wastes, applied as foliar sprays, compost tea is used for two reasons: to inoculate microbial life into the soil or into the foliage of plants and to add

Fayoum J. Agric. Res. \& Dev., Vol. 26, No.1, January, 2012 
soluble nutrients to the foliage or to the soil to feed the organisms and the plants present. (Steve,2009). Compost Tea revealed significant positive effects on tomato yield, biomass, number of fruits and root weight in comparison to the control. On the other hand, compost tea increased vitamin C content (ElHanafi Septi, 2005). Badr and Samia (2009) used foliar application with compost tea from 0 to 3 times. They found that plants sprayed once significantly surpassed those sprayed twice or 3 times compared to control plants in root and sugar yields (t/fed), sucrose\% in both seasons.

Egyptian Government imports about 1.10 milion ton of sugar every year to face the rapid increase of population. All sugar beet genotypes cultivated in Egypt are imported from foreign countries. So, it is preferable to evaluate them under Egyptian conditions especially under newly reclaimed soil, under different sowing dates and different harvesting dates to select the best suited ones. The differences between varieties in gene make up expression may be throwing some light on the relative importance of studying varieties behavior through the growing season. Osman et al. (2003) and Ismail et al. (2006) in Egypt, showed that Kawemira variety was superior in sucrose \%, root and sugar yields/fed compared to Top, Lola and Pleno varieties. Aly (2006) found that Marathon variety significantly surpassed the other varieties for root length, diameter, fresh weight, root and sugar yields/fed. While, Kawemira variety was the best for sucrose $\%$, purity $\%$, extractable sugar\% and extractability\%. Ismail et al. (2007), Shalaby et al. (2008), El-Sheikh et al. (2009) and Enan et al. (2009) showed that sugar beet varieties significantly differed in root length, diameter, fresh weight/plant, TSS\%, root and sugar yields/fed in both seasons. Farida variety significant increase of total soluble solids $\%$, sucrose $\%$, purity $\%$ and sugar yields/fed, while, it recorded the lowest values for impurities $\%$, i.e. $\mathrm{N}, \mathrm{Na}$ and $\mathrm{K} \%$ in both seasons. Soha, Khalil (2010) studied the differences between some sugar beet genotypes, the results recorded that Toro surpassed other genotypes in root length and diameter, chlorophyll a, as well as, fresh and dry root weights/plant, root and sugar yields ton/fed, while LP11 recorded the lowest results in both seasons.

The aim of this investigation is to study the effect of foliar spray with compost tea on yield and quality of some sugar beet varieties at El-Sharkia Governorate conditions.

\section{MATERIALS AND METHODS}

Two field experiments were carried out in a sandy soil at El-Qureen, Sharkia Governorate Egypt during 2009/2010 and 2010/2011 seasons to study the response of three multigerm sugar beet varieties i.e., Top, Sultan and Kawemira to foliar spraying with three compost tea levels $(0.0,1.5$ and 2.0 $\mathrm{L} / \mathrm{fed} / 300 \mathrm{~L}$ water).

The experiment treatments were randomly arranged in a split plot manner with four replications, foliar spraying with compost tea levels were arranged in the main plots and sugar beet varieties were allocated in the sub plots. The sub-plot area was $19.60 \mathrm{~m} 2$ consists 4 ridges $X 0.70 \mathrm{~m}$ apart X 7.0 $\mathrm{m}$ long. Sugar beet varieties sprayed by compost Tea after 60 and 75 days from sowing. Compost tea is a liquid produced by leaching soluble nutrients and extracting bacteria from compost. Compost tea in commercial name, was provided from Microbiology Department, Agriculture Research Center, Ministry of Agriculture, Egypt. A fixed dose of phosphorus was added in the form of calcium superphosphate $\left(15.5 \% \mathrm{P}_{2} \mathrm{O}_{5}\right)$ at the rate of $30 \mathrm{~kg} \mathrm{P}_{2} \mathrm{O}_{5} / \mathrm{fed}$

Fayoum J. Agric. Res. \& Dev., Vol. 26, No.1, January, 2012 
during land preparation. Plants were sowing in the $15^{\text {th }}$ of October on hills 20 $\mathrm{cm}$ apart in both seasons and harvested when the outside leaves of these plants turned yellow (after 210 days from sowing). The previous crop was maize in both seasons. Nitrogen fertilizer at the rate of $100 \mathrm{~kg} \mathrm{~N} / \mathrm{fed}$ was added in the form of ammonium nitrate $(33.5 \% \mathrm{~N})$ in four equal doses, the $1^{\text {st }}$ one after thinning and the other were applied at 2-week interval after the first application. Potassium fertilizer was added in the form of potassium sulfate $\left(48 \% \mathrm{~K}_{2} \mathrm{O} / \mathrm{fed}\right)$ at the rate of $36 \mathrm{~kg} / \mathrm{fed}$ in four equal doses with nitrogen fertilizer. Other agricultural practices required for growing sugar beet were carried out as usually practiced in the region. Some physical and chemical properties of the experimental soil were analyzed according to Jakson (1967) are shown in Table 1.

Table 1: Some physical and chemical properties of the experimental soil

\begin{tabular}{|c|c|c|c|c|c|c|c|c|}
\hline \multicolumn{3}{|c|}{ Particle size } & Soil & \multirow[b]{2}{*}{$\begin{array}{c}\text { E.C. } \mathrm{dS} / \mathrm{m} \\
4.10 \\
\end{array}$} & \multirow[b]{2}{*}{$\begin{array}{c}\text { Soil } \mathrm{pH}(1: 2.5) \\
8.75\end{array}$} & \multirow{2}{*}{\multicolumn{2}{|c|}{$\begin{array}{c}\text { Organic matter \% } \\
1.81 \\
\end{array}$}} & \multirow[b]{2}{*}{$\begin{array}{c}\mathrm{CaCO}_{3} \% \\
1.50 \\
\end{array}$} \\
\hline $\begin{array}{c}\text { Sand } \% \\
66.80 \\
\end{array}$ & $\begin{array}{l}\text { Silt } 9 \\
20.9\end{array}$ & $\begin{array}{c}\text { Clay } \% \\
12.30 \\
\end{array}$ & Sandy & & & & & \\
\hline \multicolumn{3}{|c|}{ Soluble Cations (meq/L) } & \multicolumn{3}{|c|}{ Soluble anions (meq/L) } & \multicolumn{3}{|c|}{ available contents (ppm) } \\
\hline $\mathrm{Ca}^{++}$ & $\mathrm{Mg}^{++}$ & $\mathrm{Na}^{+}$ & $\mathrm{CC}$ & $\mathrm{HCO}_{3}^{-}$ & & 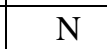 & $\mathrm{D}$ & $\mathrm{K}$ \\
\hline 6.00 & 3.10 & $14.20 \quad 0.20$ & 1.00 & 1.80 & 14.60 & 25 & 4.72 & 280.18 \\
\hline
\end{tabular}

\section{Recorded data:}

At harvest, two middle ridges of each plot were harvested to determine the following traits:
A. Vegetative traits:
1. Root length $(\mathrm{cm})$, it was measured in ten guarded plants.
2. Root diameter $(\mathrm{cm})$, it was measured in ten guarded plants.
3. Root fresh weight/g.

\section{B. Quality traits:}

Samples of twenty roots were taken randomly, send to the laboratory, cleaned with running tap water, dried, each sample was grated separately with grater into cassettes and mixed thoroughly to determined, the quality traits as follow

1. Sucrose\% was estimated in fresh samples of sugar beet roots, polarimeterically on a lead acetate extract of fresh macerated root according to Le Docte (1927).

2. Juice purity \%, it was calculated by dividing sucrose \% / TSS\% according to the method of (Carruthers et al., 1962).

3. Minerals content, i.e. $\mathrm{N} \%, \mathrm{Na} \%$ and $\mathrm{K} \%$ in beet were estimated according to AOAC (2005).

C. Productivity traits:

1. Root/fed yield (ton): plants of sugar beet from each plot were harvested topped to determine root yield fed/ ton on fresh weight basis.

2. Sugar yield/fed (ton), was calculated using the following equation:

Sugar yield $($ ton $/$ fed $)=$ Root yield $\mathrm{X}$ sucrose $\%$.

Cochran (1981).

The collected data were statistically analyzed according to Snedecor and

Fayoum J. Agric. Res. \& Dev., Vol. 26, No.1, January, 2012 


\section{RESULTS AND DISCUSSION}

\section{Compost tea effects:}

The results presented in Table (2) show that the compost tea significantly affected all studied traits in both seasons. Sprayed sugar beet plants by compost tea at the level of $2(\mathrm{~L} / \mathrm{fed})$ it gave the highest values for root length, diameter, fresh weight/plant, sucrose $\%$, purity $\%$ and yields of root and sugar/fed, while, it gave the lowest values for root minerals content $\%$ as compared with other levels in both seasons .

The increase in plant growth traits i.e. root length, diameter, fresh weight/plant and yields might be due to raising growth by increasing foliar application levels of compost tea which increased translocation of photosynthetic production to roots, therefore increased root and sugar yield/fed, as well as decrease root mineral contents in root juice these results are in harmony with those of (Steve, 2009).

The increase in quality may be due to higher sucrose\% and decreasing mineral contents led to increase in sugar and root yields/fed. These results are coincide with those findings of El-Hanafi Septi (2005) and Badr and Samia (2009).

Table 2: Effect of foliar compost tea on growth, sucrose\%, yields and root mineral contents at harvest during 2009/2010 and 2010/2011 seasons.

\begin{tabular}{|c|c|c|c|c|c|c|c|c|c|c|}
\hline \multicolumn{11}{|c|}{$2009 / 2010$ season } \\
\hline \multirow{2}{*}{$\begin{array}{l}\text { Compost } \\
\text { Tea L/fed }\end{array}$} & \multicolumn{3}{|c|}{ Growth traits } & \multicolumn{2}{|c|}{ Quality\% } & \multicolumn{3}{|c|}{$\begin{array}{l}\text { Root minerals } \\
\text { content }\end{array}$} & \multicolumn{2}{|c|}{$\begin{array}{l}\text { Yields } \\
\text { (t/fed) }\end{array}$} \\
\hline & RL & RD & RFW & Suc. $\%$ & Pur.\% & $\mathrm{N} \%$ & $\mathrm{Na} \%$ & $\mathrm{~K} \%$ & RY & SY \\
\hline 0 & 29.26 & 12.50 & 916 & 15.35 & 76.75 & 1.81 & 1.50 & 5.39 & 27.42 & 4.21 \\
\hline 1.50 & 30.42 & 13.50 & 930 & 16.50 & 82.56 & 1.68 & 1.42 & 5.27 & 28.40 & 4.69 \\
\hline 2.00 & 31.00 & 13.90 & 1111 & 17.32 & 86.60 & 1.53 & 1.31 & 5.23 & 30.34 & 5.25 \\
\hline LSD at $5 \%$ & 0.44 & 0.35 & 15.00 & 0.33 & 0.95 & 0.03 & 0.10 & 0.11 & 0.85 & 0.02 \\
\hline \multicolumn{11}{|c|}{$2010 / 2011$ season } \\
\hline 0 & 29.90 & 13.70 & 989 & 16.17 & 77.00 & 1.70 & 1.62 & 5.41 & 27.07 & 438 \\
\hline 1.50 & 31.20 & 14.14 & 1067 & 17.19 & 81.86 & 1.53 & 1.55 & 5.29 & 28.83 & 4.95 \\
\hline 2.00 & 32.80 & 16.09 & 1104 & 18.25 & 86.90 & 1.40 & 1.42 & 5.14 & 30.13 & 5.50 \\
\hline LSD at $5 \%$ & 0.16 & 0.22 & 15.00 & 0.21 & 0.87 & 0.03 & 0.12 & 0.09 & 0.66 & 0.02 \\
\hline
\end{tabular}

$\mathrm{RL}=$ root length $(\mathrm{cm}), \mathrm{RD}=$ Root diameter $(\mathrm{cm}), \mathrm{RFW}=$ root fresh weight $(\mathrm{g} / \mathrm{plant})$, Suc.$=$ Sucrose $\%$, Pur. $\%=$ Purity $\%, \mathrm{~N}, \mathrm{Na}$ and $\mathrm{K} \%=$ nitrogen, sodium and potassium content. $\mathrm{RY}=$ Root yield/fed and SY = Sugar yield/fed.

\section{Varietal differences:}

Results recorded in Table (3) indicate that the three sugar beet varieties were significantly differed in growth traits, sucrose \%, yields/fed and minerals content in both seasons.

Kawemira was the best variety where, it gave the highest values of root length, diameter, fresh weight/plant, sucrose $\%$, purity\%, root and sugar yields/fed and gave the lowest values of root minerals content percentage, i.e. $\mathrm{N} \%, \mathrm{Na} \%$ and $\mathrm{K} \%$. 
The superiorty of Kawemira variety than other varieties because it gave the highest yield components which lead to greatest yield of root and sugar/fed and increased clearly juice quality by decreasing root mineral contents. These results are in agreement with those reported by Aly (2006), El-Sheikh et al. (2009), Enan et al.(2009) and Soha, Khalil(2010).

Table 3: Varietal variation of sugar beet varieties in growth, sucrose\%, yields and root minerals content in both seasons.

\begin{tabular}{|c|c|c|c|c|c|c|c|c|c|c|}
\hline \multirow{2}{*}{$\begin{array}{c}\text { Sugar beet } \\
\text { varieties }\end{array}$} & \multicolumn{9}{|c|}{ Growth traits } & \multicolumn{2}{c|}{ Quality\% } & \multicolumn{2}{c|}{ Minerals content } & \multicolumn{2}{c|}{$\begin{array}{c}\text { Yields } \\
\text { (t/fed) }\end{array}$} \\
\cline { 2 - 12 } & RL & RD & RFW & Suc.\% & Pur.\% & N\% & Na\% & K\% & RY & SY \\
\hline Top & 29.00 & 12.50 & 932 & 15.50 & 77.50 & 1.77 & 1.50 & 5.70 & 26.82 & 4.16 \\
\hline Sultan & 30.30 & 13.20 & 970 & 16.52 & 82.60 & 1.69 & 1.41 & 5.34 & 28.78 & 4.75 \\
\hline Kawemira & 31.40 & 14.20 & 1055 & 17.16 & 85.80 & 1.55 & 1.33 & 4.85 & 30.56 & 5.26 \\
\hline LSD at 5\% & 0.65 & 0.35 & 25.05 & 0.25 & 0.75 & 0.06 & 0.08 & 0.23 & 0.95 & 0.10 \\
\hline & & & & $\mathbf{2 0 1 0} / 2011$ season & & & & \\
\hline Top & 29.70 & 13.53 & 948 & 16.24 & 77.33 & 1.82 & 1.61 & 5.60 & 26.57 & 4.31 \\
\hline Sultan & 31.30 & 14.75 & 1062 & 17.07 & 81.29 & 1.50 & 1.53 & 5.24 & 28.82 & 4.92 \\
\hline Kawemira & 32.90 & 15.65 & 1150 & 18.30 & 87.14 & 1.31 & 1.45 & 5.00 & 30.64 & 5.61 \\
\hline LSD at 5\% & 0.85 & 0.56 & 30.25 & 0.15 & 1.35 & 0.02 & 0.05 & 0.13 & 0.77 & 0.04 \\
\hline
\end{tabular}

$\mathrm{RL}=$ root length $(\mathrm{cm}), \mathrm{RD}=$ Root diameter $(\mathrm{cm}), \mathrm{RFW}=$ root fresh weight $(\mathrm{g} / \mathrm{plant})$, Suc. $=$ Sucrose $\%$, Pur. $\%=$ Purity $\%, \mathrm{~N}, \mathrm{Na}$ and $\mathrm{K} \%=$ nitrogen, sodium and potassium content. RY = Root yield/fed and SY = Sugar yield/fed.

Table 4: Interaction between compost tea treatments and varieties at harvest during 2009/2010 and 2010/2011 seasons.

\begin{tabular}{|c|c|c|c|c|c|c|c|c|c|}
\hline \multicolumn{10}{|c|}{$2009 / 2010$} \\
\hline \multicolumn{10}{|c|}{ Foliar application with compost Tea $1 /$ fed } \\
\hline Sugar beet & \multicolumn{3}{|c|}{ Sucrose \% } & \multicolumn{3}{|c|}{ Root yields (t/fed) } & \multicolumn{3}{|c|}{ Sugar yields (t/fed) } \\
\hline varieties & 0 & 1.5 & 2.00 & 0 & 1.5 & 2.00 & 0 & 1.5 & 2.00 \\
\hline Top & 14.30 & 15.45 & 16.75 & 25.12 & 26.11 & 29.23 & 3.59 & 4.03 & 4.90 \\
\hline Sultan & 15.65 & 16.80 & 17.10 & 27.57 & 28.35 & 30.42 & 4.31 & 4.76 & 5.20 \\
\hline Kawemira & 16.10 & 17.25 & 18.11 & 29.57 & 30.75 & 31.37 & 4.73 & 5.28 & 5.65 \\
\hline LSD at $5 \%$ & \multicolumn{3}{|c|}{0.35} & \multicolumn{3}{|c|}{0.10} & \multicolumn{3}{|c|}{0.16} \\
\hline \multicolumn{10}{|c|}{$2010 / 2011$ season } \\
\hline Top & 15.00 & 16.23 & 17.50 & 24.45 & 26.75 & 28.50 & 3.67 & 4.34 & 4.99 \\
\hline Sultan & 15.75 & 17.35 & 18.10 & 27.21 & 29.09 & 30.15 & 4.29 & 5.05 & 5.46 \\
\hline Kawemira & 17.76 & 17.99 & 19.15 & 29.55 & 30.62 & 31.74 & 5.18 & 5.46 & 6.05 \\
\hline LSD at $5 \%$ & \multicolumn{3}{|c|}{0.50} & \multicolumn{3}{|c|}{0.45} & \multicolumn{3}{|c|}{0.18} \\
\hline
\end{tabular}

Fayoum J. Agric. Res. \& Dev., Vol. 26, No.1, January, 2012 
III. Interaction effects:

Data tabulated in Table (4) indicate clearly that the interaction between foliar spray with compost tea levels and varieties significantly affected sucrose $\%$, root and sugar yields/fed, on the other hand insignificantly affect other studied traits in both seasons. Kawemira variety gave the highest values of obvious traits under all compost tea levels. The results also exhibited that the highest sucrose \%, root and sugar yields/fed were obtained when sown Kawemira variety and sprayed with $2.0 \mathrm{~L} / \mathrm{fed}$ compost tea as compared with other interactions in both seasons.

Generally it could be recommended that spraying sugar beet variety Kawemira with compost tea gave the highest root and sugar yield in newly reclaimed soils under El-Sharkia Governorate conditions.

\section{REFERENCES}

Aly, E.F. (2006). Effect of environmental conditions on productivity and quality of some sugar beet varieties. Ph. D. Thesis., Fac. of Agric., Benha Univ., Egypt.

AOAC (2005). Association of Official Analytical Chemists. Official Methods of analysis, $16^{\text {th }} \mathrm{Ed}$. International Washington, D.C. USA.

Badr, A.I. and Samia, M.M.H. (2009). Evaluation of injected ammonia and compost tea spraying on productivity of sugar beet. Minufiya J. Agric. Res. 34 (6): 2117-2129.

Carruthers, A.; J.F.T. Oldfield and H.J. Teague (1962). Methods for assessment of beet quality. $15^{\text {th }}$ Annual Technical Conference, British Sugar Corporation LTD. 36pp. (C.F.. The Sugar Beet Crop Book, 572$573,1^{\text {st }}$ Edition published by Chapman and Hall, Univ. Press, Cambridge, UK.).

CCSC (2010). Sugar Crops Council. Ann. Report Ministry Agric., Egypt. (In Arabic).

El-Hanafi Septi, K. (2005). Compost tea effects on soil fertility and plant growth of organic tomato (Selenium lycopersicum Mill) in comparison with different organic fertilizers. Email: occhialini and ir@iamb.it; 96 ref.. Thesis M.Sc. Italy. (C.F. Computer Research).

El-Sheikh, S.R.E.; K.A.M. Khaled and S.A.A.M. Enan (2009). Evaluation of some sugar beet varieties under three harvesting dates. J. Agric. Sci., Mansoura Univ., 34 (3): 1559-1567.

Enan, S.A.A.M.; S.R.E. EI Sheikh and K.A.M. Khaled (2009). Evaluation of some sugar beet varieties under different levels of $\mathrm{N}$ and Mo fertilization. J. Biol. Chem. Environ. Sci., 4 (1): 345-362.

Ismail, A.M.A.; A.H.S.A. Al-Laboody and N.M.S. Shalaby (2006). Variability and traits relationships in sugar beet under different sowing dates. Egypt. J. Plant Breeding, 10 (1): 387-406.

Ismail, A.M.A.; A.H.S.A. Al-Laboody and N.M.S. Shalaby (2007). Evaluation of some sugar beet varieties under different combinations of NPK fertilizers. Egypt. J. Appl. Sci., 22 (3): 77-90.

Jakson, M. (1967). Soil Chem. Analyses. Prentice Hall Inc Englewood Cliff NJ USA.

Le Docte, A. (1927). Commercial determination of sugar in the beet root using the sacks. Le-Docte Process. Int. Sug. J.,29: 488-492.

Fayoum J. Agric. Res. \& Dev., Vol. 26, No.1, January, 2012 
Osman, A.M.H.; G.S. El-Sayed; M.S.H. Osman and K.S. El-Sogheir (2003). Soil application of some microelements with relation to yield and quality of sugar beet varieties. Annals of Agric. Sc., Moshtohor, 41 (3): 1071-1088.

Shalaby, N.M.S.; A.H.S.A. Al-Labbody and S.R.E. El-Sheikh (2008). Covariability of yield and quality of twenty sugar beet genotypes. Egypt. J. Plant Breed., 12 (1): 267-277.

Snedecor, G.W. and W.G. Cochran (1981). Statistical Methods. $6^{\text {th }}$ Ed. Iowa State Univ. Press. Ames. Iowa., USA.

Soha, Khalil, R.A.E. (2010). Study of performance and behavior of some sugar beet varieties under different environmental conditions. Ph.D. Thesis., Fac. Agric., Fayoum Univ., Egypt.

Steve, D. (2009). Compost tea frequently asked questions. www. attar. org. sustainable. Growth, Inc. 2116 N. $28^{\text {th }}$ Street Boise, ID83703. (C.F. Computer Search).

$$
\begin{aligned}
& \text { إستجابة بعض أصناف بنجر السكر للرش بالكمبوست تحت ظروف الأراضى حديثة الإستصلاح }
\end{aligned}
$$

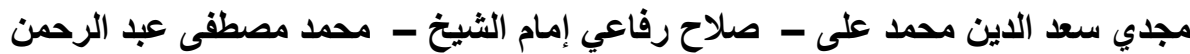

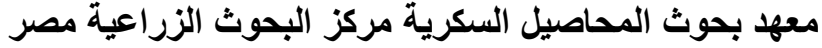

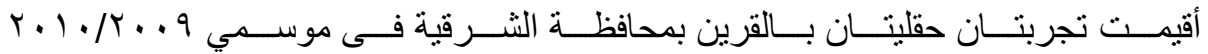

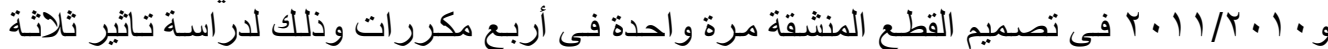

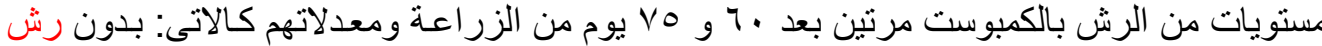

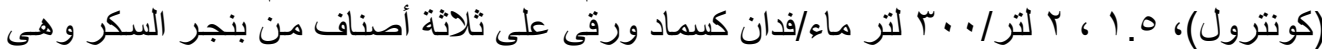

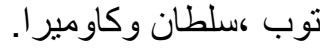

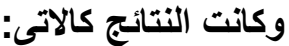

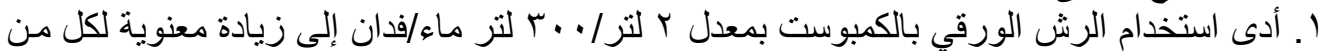

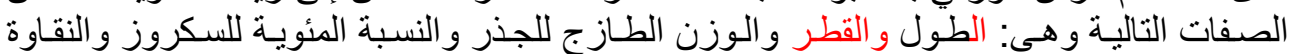

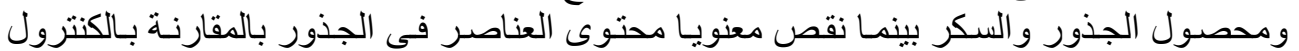

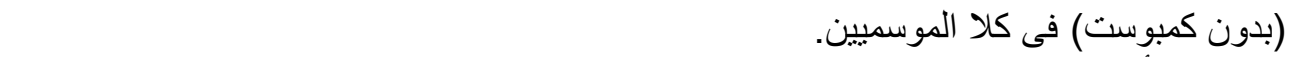
r. اختلفت الأصناف معنويا فى صفات طول وقطر ولفر ووزن الجذر و النسبة المئويـة للسكروز و النقاوة

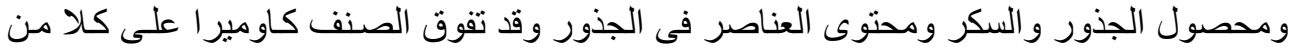

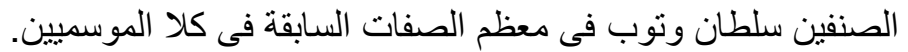

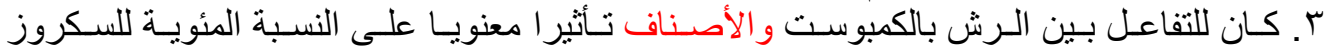

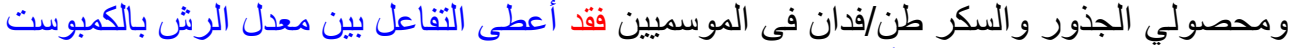

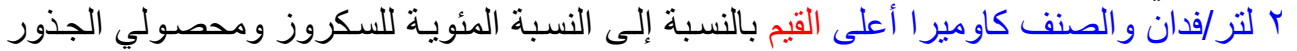

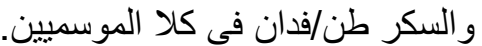

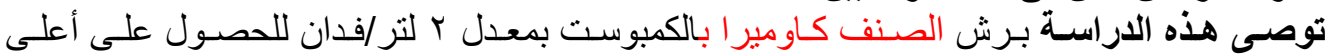

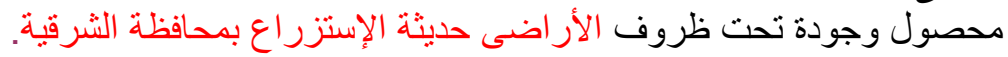

